\title{
INVITEDREVIEW
}

\section{Ethnoveterinary medicine for responsible dairying}

\author{
Dilip Rath ${ }^{1}$, Girish Kumar Sharma ${ }^{1}$ and Yogesh C Joshi ${ }^{2}$
}

Received: 17 September 2020 / Accepted: 23 September 2020 / Published online: 27 October 2020

(C) Indian Dairy Association (India) 2020

\begin{abstract}
India is the largest milk producer in the world with 22 percent of the global share and engages around 6.3 crore rural households. The cost and availability of animal health services for small dairy holders in a country like India has always been a cause of concern. There is a growing apprehension about the presence of drug residues in milk and milk products as well emergence of drug resistant bacteria and its associated health risks due to indiscriminate use of these products. The cost of therapeutic medicines, antimicrobial resistance and the residues in milk, meat and other animal products have forced the animal health sector to look for alternate forms of therapy to overcome these deficiencies. The new alternatives should be affordable, farmer friendly and lead to minimal or no residues in milk and other products. Practice of Ethno-Veterinary Medicine (EVM) is an approach that fulfils the above criteria. However, animal health service providers have very limited knowledge about EVM which in India is largely based on Veterinary Ayurveda. EVM has been used throughout the world by traditional animal rearing communities. EVM has been used for most common ailments in almost all domestic animal species. While there are efforts to document these practices, such documents are not widely available. Only recently, scientific scrutiny of these treatments for efficacy, mode of action and active ingredients has been initiated.
\end{abstract}

\footnotetext{
${ }^{1}$ National Dairy Development Board, Anand-388 001, Gujarat, India Email: diliprath2008@yahoo.in
}

${ }^{2}$ G. H. Patel Post Graduate Institute of Business Management, Sardar Patel University, Vallabh Vidyanagar, Anand- 388 120, Gujarat, India Email: joshiyogesh_2000@yahoo.com

Dilip Rath $(\bowtie)$

National Dairy Development Board, Anand-388 001, Gujarat, India Email : diliprath2008@yahoo.in
National Dairy Development Board (NDDB) along with Sabarkantha District Cooperative Milk Producers Union, Sabarkantha, Gujarat and Trans-Disciplinary University, Bengaluru, evaluated the use of EVM initially for management of bovine mastitis and subsequently for management of other common ailments of dairy animals. It was observed that EVM was helpful in successfully managing mastitis $(85 \%)$, diarrhoea (86\%), fever (85\%), indigestion $(87 \%)$, anoestrus $(77 \%)$, worm infestation $(89 \%)$, wound healing $(79 \%)$ and ecto-parasite infestation (87\%) with high clinical cure rate. It was economical compared to conventional allopathic treatment. A reduction in residues of common antibiotics (quinolones, tetracycline, sulphonamide, B-lactam) in milk was observed in the area of operation. Drug resistant bacteria (S. aureus including methicillin resistant S. aureus - MRSA; and E. coli including Extended Spectrum Beta Lactamase producing - E. coli - ESBL), were isolated from the milk of bovines suffering from mastitis. EVM was able to cure even these animals. However, awareness about EVM is limited among animal health service providers and other stakeholders. EVM needs to be given adequate focus and mainstreamed. This would entail concerted efforts and initiatives in policy, research and development and infrastructure.

Keywords: Antimicrobial resistance; Antibacterial residues; Drug residues; Ethnoveterinary medicine; Ethnoveterinary practice; Mastitis;Veterinary Ayurveda; Veterinary herbal medicine

\section{Introduction}

Globally, dairying has a significant role as it generates employment and provides livelihood to about 1 billion people through 150 million dairy farms and provides healthy and nutritious milk and milk products to billions of customers every day. India -the largest producer of the milk in the world, with a share of around $22 \%$, engages about 6.3 crore rural households in dairying. The value of milk group output was at ₹ 7,01,530 crore in 2017-18. With such large social and financial engagement, dairying needs to be responsible and sustainable in terms of product quality for the customer and animal health and welfare for the producer. The cost and availability of animal health services for small dairy holders is a concern. At the same time, there is a growing concern 
about the presence of drug residues in milk and milk products and its associated health risks (Bacanli and Basaran, 2019). Further, there is an emergent alarm regarding the development of drug-resistant bacteria with enormous health consequences. Recognising the importance, the World Health Organization (WHO) has developed the global action plan (WHO, 2015), guidelines for developing national action plans (WHO, 2016) and is monitoring the global progress (WHO, 2018). India has also prepared the national action plan (GOI, 2017), but has made little progress on appropriate use of antibiotics in animals and on following the guidelines on milk withholding period, subsequent to administration of drugs. While, the current status requires us to develop plans for judicious use of medicines at one end, it also calls to search for alternate forms of practices where such precautions may not be required. Application of Ethno-Veterinary Medicine (EVM) could play a pivotal role in addressing these issues and help in delivering safe milk and milk products to consumers while making animal health affordable to small holders.

\section{What is EVM}

Ethno-Veterinary Medicine is defined as "The holistic, interdisciplinary study of local knowledge and its associated skills, practices, beliefs, practitioners, and social structures pertaining to the healthcare and healthful husbandry of food, work, and other income-producing animals, always with an eye to practical development applications within livestock production and livelihood systems and with the ultimate goal of increasing human wellbeing via increased benefits from stockraising." (McCorkle, 1998)

However, the general understanding of EVM is that it is a compilation of people's traditional practices, knowledge, and beliefs to keep their animals healthy, productive and performing, using local resources in a sustainable manner. While in a few countries EVM uses animal origin products also, a significant part of EVM is based on the use of locally available herbs or plants and other local natural ingredients. Most of the pastoral and animal rearing communities in different countries have generated this knowledge over generations.

In India, EVM is largely the practice of Veterinary Ayurveda. Early written accounts describing the medicinal use of plants are found in the ancient Vedic texts. These writings originated in the period circa 3147 BC (Silver, 2007). Chapters that discuss animal husbandry appear in Skanda Purana, Devi Purana and other lesser known texts. Palkapya, around 1000 BC and Shalihotra, around $2350 \mathrm{BC}$ specialized in the treatment of horses and elephants respectively. Shalihotra compiled an Indian Materia Medica which provided step-by-step descriptions of methods of administration of herbs, including instructions on preparing injectables. The first book on veterinary medicine was written by Shalihotra in Sanskrit and describes specific techniques in veterinary medicine, including the use of indigenous herbs in the treatment of working animals.

EVM has been used in most of the domestic and zoo animals for example in cattle, buffalo, sheep, goat, pig, dog, horse, camel, elephant and birds. Practice of EVM is documented in many developing countries and some developed countries likeArgentina, Botswana, Cameroon, Canada, India, Italy, Kenya, Pakistan, PR China, Romania, South Africa, Switzerland, Turkey and Zimbabwe.

EVM has been used for management of most common diseases like mastitis (Nair and Punniamurthy, 2017), parasitic infestations (Sanhokwe et al. 2016), liver fluke (Jeyathilakan et al. 2012), gastrointestinal nematode (Ademola et al. 2006), ecto-parasite (Nyahangare et al. 2015), ticks (Nimbalkar et al. 2020), wound healing (Marume et al. 2017), respiratory disease (Ayrle et al. 2016), reproductive disorders (Dey et al. 2020) and fungal infections (Dikhoba et al. 2019).

EVM has also been used for specific viral diseases, e.g. Rabies, Bovine herpesvirus-1, Rotavirus, Bovine viral diarrhoea (ZitterlEglseer and Marschik, 2020), Foot and mouth disease (Kpodékon et al. 2015), African swine fever (Fasina et al. 2013), Infectious bursal disease (Ganguly et al. 2020), and Porcine reproductive and respiratory syndrome (Kaewprom et al. 2015).

In India, ethno-veterinary practices have been documented in almost all parts of the country since many decades - Andhra Pradesh, Assam, Arunachal Pradesh, Bihar, Chhattisgarh, Gujarat, Haryana, Himachal Pradesh, Jammu and Kashmir, Jharkhand, Karnataka, Kerala, Madhya Pradesh, Maharashtra, Manipur, Meghalaya, Nagaland, Odisha, Punjab, Rajasthan, Sikkim, Tripura, Uttar Pradesh, Uttarakhand and West Bengal.

Some of the widely used herbs for EVM in India are Aloe vera, Curcuma longa, Azadirachta indica, Murraya koenigii, Cissus quadrangularis, Mimosa pudica, Acalypha indica, Lantana camara, Acorus calamus, Leucas linifolia, Adhatoda vasica, Moringa oleifera, Gentiana chirayita, Ocimum sp., Ocimum basilicum, Papaver somniferum, Piper betle, Tamarindus indica, and Lawsonia inermis. Spices commonly used are cumin, fenugreek, pepper, coriander, bay leaves, asafetida and chilly. Vegetables and fruits commonly used are garlic, ginger, onion, lemon, bitter gourd, radish, lady finger, coconut and mustard. Other ingredients include limestone, coconut oil, sesame oil/ gingelly oil, salt, jaggery, ghee and butter. Based on scientific studies, pharmacopoeial monographs for 57 crude herbs and 47 processed herbs/excipients were published in Indian Pharmacopoeia 2014. (Rastogi et al. 2015).

\section{EVM, Drug residues and Antimicrobial Resistance (AMR)}

The emphasis on enhancing the productivity of dairy animals has, besides enhancing milk production, also resulted in an 
increased use of agro-chemicals, mainly antibiotics and antiparasite drugs. The residues of these drugs, could leak into the environment including milk. Public health can also get affected due to residues in milk. Antibiotic residues may cause various toxic effects such as allergy, immunopathological effects, carcinogenicity (sulphamethazine, oxytetracycline, furazolidone), mutagenicity, nephropathy (gentamicin), hepatotoxicity, reproductive disorders, bone marrow toxicity (chloramphenicol), anaphylactic shock and development of antimicrobial resistance in bacteria which may cause serious infection in humans (Darwish et al. 2013).

Withdrawal periods reflect the duration of time necessary for an animal to metabolize an administered drug and the amount of time necessary for the drug/ product concentration level to decrease to a safe, acceptable level in milk. Treatment with antimicrobials in dairy animals usually requires withdrawal periods of 6-7 days for collection of milk. This practice is not genuinely followed by all farmers due to economic reasons and allows milk with residues to reach customers. However, in large dairies the residues in milk get substantially diluted after getting mixed with the normal milk.

Considering the health hazards associated with various drugs, maximum permissible limits for their residues are fixed internationally by Codex (CODEX, 2015) and Food Safety and Standards Authority of India (FSSAI) for India. India is among the leading producer and consumer of antibiotics (Van Boeckel et al. 2014).

Studies documenting the presence of antibiotic residues in milk in India are limited. Anational milk survey in 2018 in India recorded $1.2 \%$ samples with antibiotic residues with Oxytetracycline being the main antibiotic (FSSAI, 2018). A compilation of antibiotic residues identified in milk in India by various authors is mentioned in Table 1.

The use of EVM for treatment of ailments of animals reduces the use of contemporary allopathic drugs to a considerable extent resulting in reduced presence of drug residues in animal products. Use of EVM for reducing the drug residues in animal products is a sensible approach and has been described by various workers (Groot and van't Hooft, 2016; Nair, 2019). In fact, use of medicinal plants is considered important for organic livestock farming in Europe (Mayer et al. 2014).

\section{EVM and Antimicrobial resistance (AMR)}

Antimicrobial resistance (AMR) is a complex, multifaceted problem that threatens human and animal health, the global economy, as well as national and global health security. WHO has included AMR as one of the top ten threats to global health in 2019 (WHO, 2019). Current 'One Health' approaches to AMR focus primarily on reduction in antibiotic usage in food animals.

With a few exceptions where certain classes of antibiotics are restricted for human or animal use, most antibiotics are used both in human and animal (FAO, 2016). Unregulated, indiscriminate use of antibiotics as well as under or excessive dosing is the leading cause of AMR. Use of veterinary antimicrobials without the prescription of a veterinarian was reported in $87 \%$ and $38 \%$ among urban and rural farmers, respectively (Sudershan and Bhat, 1995).

Various types of antibiotic resistant bacterial agents have been isolated from bovine mastitis milk. Among them, methicillin

Table 1 Presence of antibiotic residues in milk, reported from India

\begin{tabular}{|c|c|c|c|c|c|c|c|c|c|c|}
\hline \multirow[t]{2}{*}{ Study location } & \multirow[t]{2}{*}{ Year } & \multicolumn{8}{|c|}{ Antibiotic residues detected in milk } & \multirow[t]{2}{*}{ Author } \\
\hline & & 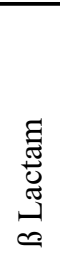 & 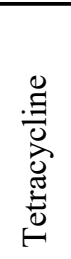 & 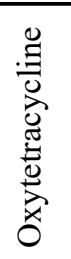 & 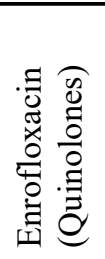 & 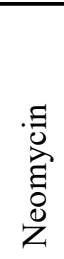 & 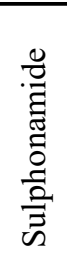 & 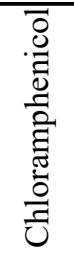 & 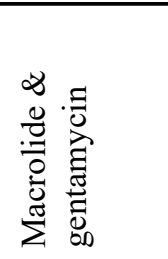 & \\
\hline$\overline{\text { Andhra Pradesh }}$ & 2015 & $\mathrm{P}$ & $P$ & $P$ & & & & & & (Kalla et al. 2015) \\
\hline Assam & 2015 & $\mathrm{P}$ & $\mathrm{P}$ & & $\mathrm{P}$ & $\mathrm{P}$ & $\mathrm{P}$ & $\mathrm{P}$ & $\mathrm{P}$ & (Lundén, 2015) \\
\hline Bihar & 2017 & & $\mathrm{P}$ & $\mathrm{P}$ & & & $\mathrm{P}$ & & & (Nirala et al. 2017) \\
\hline Punjab & 2014 & & $\mathrm{P}$ & & & & & & & (Gaurav et al. 2014) \\
\hline Punjab & 2019 & $\mathrm{P}$ & & $\mathrm{P}$ & $\mathrm{P}$ & & $\mathrm{P}$ & & & (Moudgil et al. 2019) \\
\hline Kerala & 2018 & $\mathrm{P}$ & $\mathrm{P}$ & & $\mathrm{P}$ & & & & & (Kumarswamy et al. 2018) \\
\hline Kerala & 2020 & & & $\mathrm{P}$ & & & & & & (Hebbal et al. 2020) \\
\hline Kerala & 2017 & $\mathrm{P}$ & $\mathrm{P}$ & & & & & & & (Lejaniya et al. 2017) \\
\hline Telangana & 1995 & & & $\mathrm{P}$ & & & & & & (Sudershan and Bhat, 1995) \\
\hline
\end{tabular}

$\mathrm{P}=$ Presence of antibiotic residue detected in milk 
resistant $S$. aureus and Extended Spectrum Beta-Lactamase (ESBL) producing E. coli are considered serious human health hazard.

In India several studies on the antibiotic resistance pattern of the circulating bacteriological agents have been undertaken which indicated varying degree of resistance to frequently used antibacterial agents.

In West Bengal, 54.5\% E. coli strains isolated from milk showed the capability of producing ESBL, both phenotypically and genotypically with the presence of $b l a_{\text {СтХ-м }}$ gene. The strains exhibited varying degree of resistance to drugs such as cefotaxime, ceftazidime, amoxicillin/clavulanic acid, tetracycline, and gentamicin (Batabyal et al. 2018). In Uttar Pradesh and New Delhi all E. coli strains isolated were resistant to ceftriaxone, cefepime, cefotaxime, ceftazidime, aztreonam, ampicillin and carbenicillin. The resistance was varying from $97.61 \%$ to $14.28 \%$ for Sulfadiazine, cefpodoxime, nalidixic acid, tetracycline, ciprofloxacin, sulphamethoxazole and trimethoprim, doxycycline, kanamycin, chloramphenicol, amoxicillin-clavulanic acid and gentamicin (Sivakumar et al. 2020).

In another study in West Bengal, a total of 450 composite milk samples both from cattle with or without mastitis were collected. Nine (9.6\%) S. aureus isolates were detected as MRSA and all the MRSA isolates were multidrug resistant (Mahanti et al. 2020).

In Tamil Nadu, a total of 89 positive isolates of $S$. aureus were obtained from 258 raw milk samples screened (34.49\%), of this 24 $(24 / 258 ; 9.3 \%)$ samples and $(24 / 89 ; 26.96 \%)$ isolates were positive for MRSA (Deepak, 2020).

In Jharkhand, both MRSA and non MRSA were isolated from milk samples. Based on the antimicrobial sensitivity results, MRSA isolates were found resistant to, cloxacillin, penicillin, methicillin and oxacillin. Similarly, non MRSA isolates were found resistant to penicillin, cloxacillin and cefazolin (Kumari et al. 2020). In another study in Tamil Nadu, from the milk samples of 35 cows with mastitis, $S$. aureus was isolated from $40 \%$ samples and all samples were MRSA (Manimaran et al. 2020).

In Rajasthan, 73 S. aureus strains were obtained from bovine raw milk and $90 \%$ strains were multidrug resistant, of which 15 were methicillin resistant (Sharma et al. 2017).

In Kashmir, a total of 80 (53.33\%) S. aureus isolates were recovered from cases of bovine mastitis of which 20 (25\%) were methicillin ( $m e c A)$ gene positive. In vitro antibiotic sensitivity testing of MRSA revealed complete resistance towards methicillin and other penicillin group of antibiotics (Shah et al. 2019).

In view of the above, EVM is advocated for combating antimicrobial resistance (Nair et al. 2015; Ranganathan, 2017).

\section{EVM is farmer friendly and less resource intensive}

Most preparations of EVM are made from the ingredients that exist either in kitchen of the animal owner or in nature as vegetable, fruits or herbs. These ingredients are easily available and are very affordable. The method of preparation of EVM is also simple and uncomplicated. It avoids cost and efforts taken to go to town to consult the veterinarian and visit the pharmacy to get the medicine. EVM has been suggested as a sustainable approach for mastitis control (Rana et al. 2019). EVM is a tool for poverty reduction through increasing productivity of small ruminants by using locally available economical remedies (Iqbal et al. 2005).

India has a shortage of veterinary and para-veterinary professionals. A study in 2013 estimated the number of veterinary graduates at around 41,000, and forecasted additional annual requirement of 5000 veterinary graduates and thrice this number the para-vets to meet the requirement (Agrawal et al. 2013). The policy paper of National Academy of Veterinary Sciences, highlights acute shortage of veterinary personnel in India and lists various suggestions for meeting the shortfall (NAVS, 2015a). Use of EVM by farmers for common ailments of animals will considerably reduce the workload of veterinarians enabling them to focus on serious medical cases where their professional knowledge and expertise is most needed.

\section{NDDB's Experience with Ethnoveterinary Medicine}

Mastitis is one of the leading economically important diseases of bovines in India with an annual loss of ₹ 7165.51 crore estimated in 2009. More losses were recorded in sub-clinical mastitis (₹ 4151.16 crore) than clinical mastitis ( $₹ 3014.35$ crore) (Bansal and Gupta, 2009). The contemporary management of mastitis includes testing of milk samples by California Mastitis Test (CMT) and antibiotic treatment usually infused in the udder through teats.

Information Network for Animal Productivity and Health (INAPH) is a software developed by NDDB that identifies each animal with a unique identification number printed on the ear-tag and records individual animal-wise various events related to breeding, feeding and health (Harikumar et al. 2015). Sabarkantha District Cooperative Milk Producers' Union (Sabar Dairy) in Gujarat was the first milk producers' cooperative to ear-tag all the cattle and buffaloes in their area and record diseases and treatment data. The data collected during 2013 indicated that mastitis was the leading problem. In year 2014, NDDB initiated a project to control mastitis at Sabarkantha district in association with Sabar Dairy. Testing of milk by CMT and administration of Tri Sodium Citrate (TSC) to CMT positive animals was the initial approach. TSC has been used for treating animals suffering with mastitis (Dhillon et al. 1995; Manzoor et al. 2020). Of the 19,259 SCM CMT positive animals given TSC oral regimen, $69.92 \%$ became CMT negative after the first TSC dose. In another study, in 218 animals, when two consecutive TSC regimens were provided, recovery rate was 


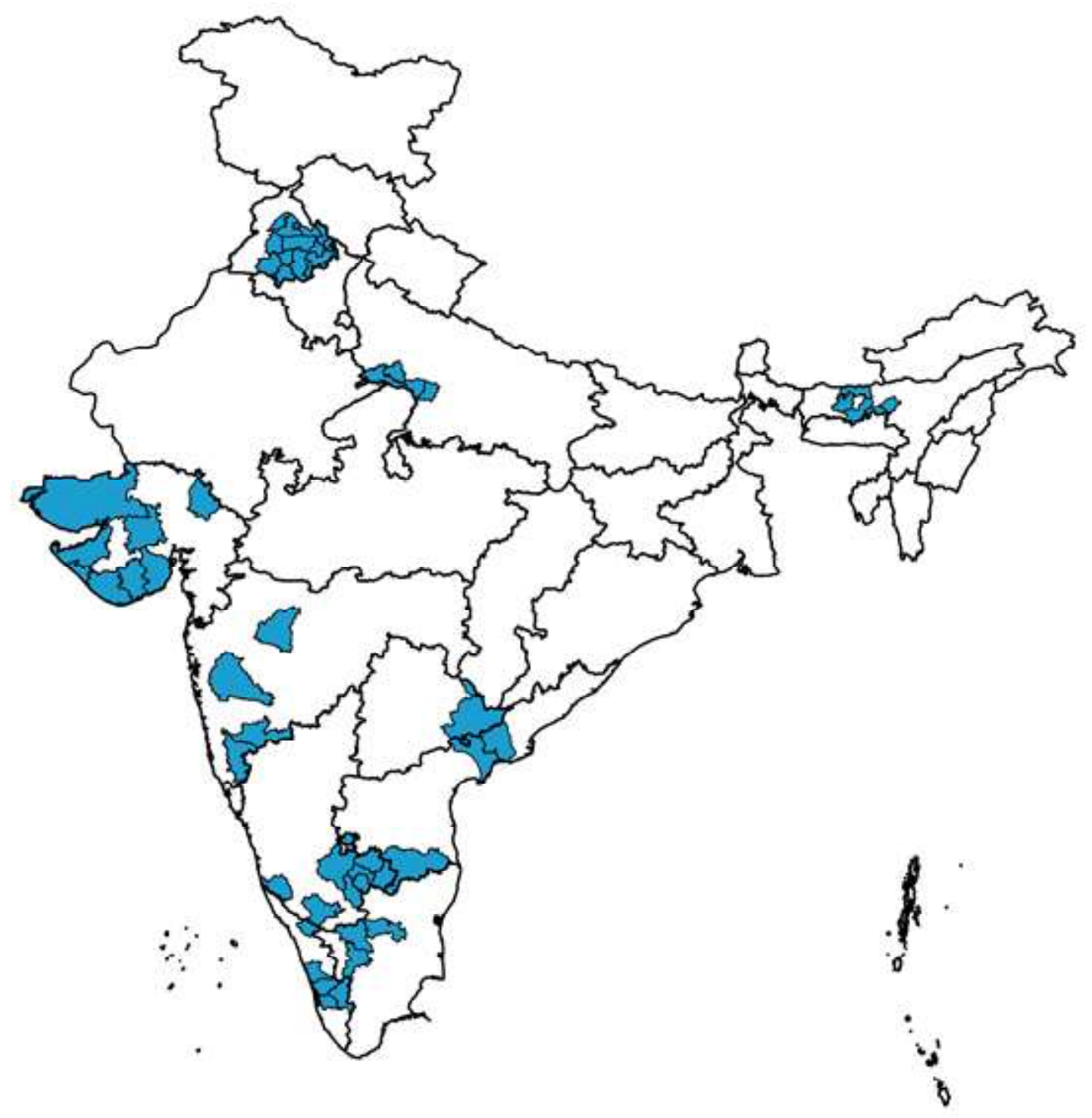

Fig. 1 Representative map of India displaying various districts included in Mastitis Control Popularization Project (MCPP)

recorded as high as $89 \%$ (Dutta et al. 2017). Use of EVM preparation made from medicinal plants, spices and other locally available traditional ingredients for treating clinical mastitis was initiated in 2016 in collaboration with Trans-Disciplinary University, Bengaluru (TDU). The veterinary doctors of the Sabar Dairy were trained at TDU who later became the trainers for other local veterinarians, and in turn delivered the EVM to the ailing animals at farmer's doorstep and demonstrated to farmers how to deliver EVM preparation so that the farmers can perform it without any help from the veterinarian. The EVM for mastitis consisted of a paste prepared fresh from Aloe vera, Curcuma longa and calcium hydroxide. The use of Aloe vera, Curcuma longa and calcium hydroxide for mastitis treatment has been evaluated (Nair and Punniamurthy, 2017). EVM formulations containing
Curcuma longa for treating mastitis have been tried by other workers also (Aruna et al. 2019; Bhatt et al. 2014).

In total, in Sabar Dairy, during 2017-2020, around 67,833 mastitis cases were treated with $85 \%$ recovery rate. The NDDB study found that the cost of treatment of mastitis through EVM was much lower than that of conventional treatment using antibiotics. This study indicated that the alternate approach employing the use of TSC for treatment of sub-clinical mastitis and EVM for treatment of clinical mastitis was very effective. Encouraged with these results, a Mastitis Control Popularization Project (MCPP) was launched by NDDB in 2017 which now covers more than 1500 villages (dairy cooperative societies) in 24 dairy cooperatives organizations spread in 9 states as shown in Figure 1. 
Some 235 veterinarians have been trained in practicing EVM at TDU, Bangalore who have now trained around 680 fellow veterinarians and 5220 field milk testing personnel. For creating awareness and interest among farmers, 344 demonstration plots have been established by planting various herbs used in EVM. From about 7.3 lakh CMT done under the project on pooled milk samples, about $21 \%$ samples were recorded positive for subclinical mastitis. Of the 92,917 clinical mastitis cases treated with EVM, 72,129 got clinically cured providing a recovery rate of $79.78 \%$.

In NDDB Study, presence of antibiotic residues in bulk milk samples was tested with the use of rapid antibiotic residue kits (Unisensor, Belgium) - test suitable for field testing. The total number of samples tested during 2017-18, 2018-19 and 2019-2020 were 790,617 and 1124 respectively. It was observed that there was reduction in milk samples having presence of Quinolones group of antibiotics in milk from $13 \%$ to $2 \%$; Tetracycline from $1 \%$ to $0.4 \%$; Sulphonamides from $15 \%$ to $3 \%$ and Beta Lactams from $25 \%$ to $9 \%$ during the observation period.

NDDB study on bacterial agents isolated from the clinical and sub-clinical mastitis cases revealed the presence of Streptococcus uberis (19\%), S. aureus (14\%), Streptococcus dysgalactiae (14\%), Streptococcus agalactiae (4\%), Klebsiella sp. $(7 \%)$ and E. coli (5\%). Studies on anti-microbial resistance with isolated strains of $S$. aureus, Klebesiella sp. and E. coli revealed that 14,50 and $18 \%$ isolates respectively were multidrug (three or more antibiotics) resistant to various classes of antimicrobials like penicillins, cephalosporins, tertracyclines, gentamicin, trimethoprim/sulfamethoxazole etc. Around 30\% S. aureus isolates were resistant to methicillin (Rana et al. 2019). These Livestock-associated MRSA (LA-MRSA) strains were first described in the initial years of the 2000s and after a decade, now pose a risk of transmission to animal handlers and veterinarians (Cuny et al. 2015). In NDDB study, based on $p v l$ gene analysis, two isolates recovered from mastitis milk were typed as community-acquired $S$. aureus. The presence of ESBL-E. coli was $11 \%$ of the total $E$. coli isolates recovered from mastitis. Based on gene profiling study by NDDB of 17 virulence and toxin producing genes, all E. coli isolates were expected to be less virulent/potent in causing human infection and food poisoning. Apart from the resistance to antibiotics in these organisms, the other impediment is the ability of these bacteria to form biofilm. Bacterial biofilms are highly recalcitrant to antibiotic therapies due to multiple tolerance mechanisms
(Olivares et al. 2020). A preliminary study by NDDB revealed that around $90 \%$ of isolated organisms namely $S$. aureus (Rana et al. 2019) and E. coli from mastitis milk had biofilm forming genetic determinants.

In NDDB study, the EVM was able to successfully treat even those mastitis cases in cattle and buffaloes where the causative agents like $S$. aureus, E. coli and Streptococcus sp. having varying degree of AMR and biofilm forming ability were isolated.

NDDB expanded the scope of EVM to treat diarrhoea and fever in addition to mastitis. The clinical cure rate was $97.41 \%$ (1958 cured from 2240 treated) for diarrhoea and 97.79\% (1691 cured from 1627 treated) for fever (Dutta et al. 2020). NDDB further expanded the scope of EVM for management of other common health conditions of dairy animals, namely indigestion, anoestrus, infestation with worms and ticks and wound healing, besides mastitis, diarrhoea and fever. NDDB is currently studying the efficacy of EVM in management of these common health conditions in the MCPP. The comprehensive results of clinical recovery are shown in Table 2 and are very promising.

\section{Future outlook}

Field studies by NDDB clearly demonstrate that EVM is very effective in management of mastitis, diarrhoea, fever, indigestion, anoestrus, infestations of worms and ticks and healing of wound. EVM is an efficacious, affordable and farmer-friendly clinical intervention for common health problems of dairy animals. EVM may be considered as a first-line-of-action in bovine health management and those not responding to EVM may be treated with allopathic drugs. Since, most EVM preparations could be delivered by the farmer himself with local resources, treatment would start early and would not be dependent on availability of a veterinarian. As India and many other developing countries face a shortage of qualified veterinary graduates, practice of EVM by farmer to manage minor animal health problems would help organize animal health delivery with reduced veterinary infrastructure and much lesser cost. This will also avoid delays in treatment of animals thus improving the health for continued productivity.

EVM usage suffers from low level of adoption by farmers as it is not recommended as first choice by the veterinary practitioners. It is also not very popular among scientific community and policy planners. Therefore, Research and Development efforts, to find in-vitro and in-vivo efficacy, active ingredients, mode of action,

Table 2 Various common health conditions of bovines treated by EVM in Mastitis Control Popularization Project (MCPP)

\begin{tabular}{llllllll}
\hline & Diarrhoea & Fever & Indigestion & Anoestrus & $\begin{array}{l}\text { Worm } \\
\text { infestation }\end{array}$ & $\begin{array}{c}\text { Wound } \\
\text { parasites }\end{array}$ \\
\hline Cases treated & & & & 13655 & 7979 & 3629 & 2749 \\
Cases clinically cured & 65508 & 64223 & 14129 & 10538 & 7080 & 2882 & 2381 \\
Cure percent (\%) & 56302 & 54512 & 12239 & 77.17 & 88.73 & 79.42 & 86.61 \\
\hline
\end{tabular}


dosage, safety, formulations for convenient delivery, shelf life, setting of quality standards etc. are required to be established and widely circulated. The Policy paper of National Academy of Veterinary Sciences (India) also makes several recommendations which include capacity building of veterinary graduates in herbal medicine, strengthening of R\&D and short as well as long term policy and development issues (NAVS, 2015b). Veterinary Council of India and Indian Council of Agricultural Research have a significant role to play in mainstreaming EVM.

EVM needs a big push for its popularization among farmers through demonstrations and vocational training. Regional compilation of EVM practices should be encouraged and authenticated. Good practices for herbal cultivation, harvest, processing and storage must be documented.

\section{Conclusions}

EVM is a practical, effective, affordable and sustainable approach for management of common animal health problems of bovine. This will also reduce the usage of antibiotics and thus their residues in livestock products and emergence of drug resistant bacteria - both of which have severe human health implications. However, EVM needs mainstreaming and focus. By practicing EVM not only we can revitalize our age old knowledge of Veterinary Ayurveda, we also protect our animals, humans and the environment which is the hallmark of responsible dairying.

\section{Acknowledgements}

Authors duly acknowledge the technical support and expertise extended by the Trans-Disciplinary University, Bengaluru. Authors are also immensely thankful to the Sabarkatha District Cooperative Milk Producers Union, Sabarkantha and other Milk Producers Unions participating in Mastitis Control Popularisation Project.

\section{References}

Ademola IO, Fagbemi BO, Idowu SO (2006) Anthelmintic efficacy of Nauclea Latifolia extract against gastrointestinal nematodes of sheep: In vitro and in vivo studies. Afr J Trad CAM 4: 148-156

Agrawal R, Rao DR, Rao B, Nanda S, Kumar I (2013) Forecasting manpower requirement in Indian veterinary and animal husbandry sector. Indian J Anim Sci 83: 667-672

Aruna M, Ambica G, Lakshmi K, Swathi B, Padmaja K (2019) Efficacy of herbal preparations in the therapy of sub clinical mastitis in cows of periurban areas of Hyderabad. Pharma Innov J 8: 186-188

Ayrle H, Mevissen M, Kaske M, Nathues H, Gruetzner N, Melzig M, Walkenhorst M (2016) Medicinal plants - prophylactic and therapeutic options for gastrointestinal and respiratory diseases in calves and piglets? A systematic review. BMC Veterinary Research 12: 89

Bacanli $\mathrm{M}, \mathrm{Ba}^{\circ}$ aran N (2019) Importance of antibiotic residues in animal food. Food Chem Toxicol 125: 462-466

Bansal B, Gupta D (2009) Economic analysis of bovine mastitis in India and Punjab - A review. Indian J Dairy Sci 62(5): 337-345
Batabyal K, Banerjee A, Pal S, Dey S, Joardar SN, Samanta I, Isore DP, Singh AD (2018) Detection, characterization, and antibiogram of extended-spectrum beta-lactamase Escherichia coli isolated from bovine milk samples in West Bengal, India. Vet World 11: 14231427

Bhatt VD, Shah TM, Nauriyal DS, Kunjadia AP, Joshi CG (2014) Evaluation of a topical herbal drug for its in-vivo immunomodulatory effect on cytokines production and antibacterial activity in bovine subclinical mastitis. Ayu 35: 198-205

CODEX (2015) Maximum Residue Limits (MRLs) and Risk Management Recommendations (RMRs) for residues of veterinary drugs in foods. CAC/MRL 2-2015. Codex Alimentarius Commission, Food and Agriculture Organisation, Rome

Cuny C, Wieler LH, Witte W (2015) Livestock-Associated MRSA: The impact on humans. Antibiotics 4: 521-543

Darwish WS, Eldaly EA, El-Abbasy MT, Ikenaka Y, Nakayama S, Ishizuka M (2013) Antibiotic residues in food: the African scenario. Jpn J Vet Res. 61: S13-22

Deepak SJ, Porteen K, Elango A, Kumar TMAS, Babu RN, Sureshkannan S, Ruban SW (2020) Occurrence of methicillin resistant Staphylococcus aureus from bovine raw milk in Chennai. J Anim Res 10: $27-31$

Dey S, Sarkar B, Paul S (2020) Ethno-veterinary practices for the management of reproductive disorders in dairy animals in rural Punjab. J Entomol Zool Stud 8: 1595-1598

Dhillon KS, Singh TJ, Sodhi SS, Sandhu, HS, Dwivedi PN, Gilu RBS (1995) Milk bacteriology: Pre-and post trisodium citrate mastitis treatment in buffaloes. Indian J Anim Sci 65: 9-11

Dikhoba PM, Mongalo NI, Elgorashi EE, Makhafola TJ (2019) Antifungal and anti-mycotoxigenic activity of selected South African medicinal plants species. Heliyon 5 https://doi.org/10.1016/ j.heliyon.2019.e02668

Dutta P, Harikumar AV, Patel SB, Patel NA, Patel AS, Sharma GK (2017) Prospects of controlling Sub-clinical mastitis in cattle and buffaloes through the use of trisodium citrate. Indian Dairyman 69: 62-65

Dutta P, Harikumar AV, Rana SK, Patel SB, Patel DD, Patel KR, Punniamurthy N, Nair MNB, Sharma GK (2020) Management of comom ailments of dairy animals with ethno-veterinary herbal preparations in Gujarat. Pharma Innov J SP-9 : 67-70

FAO (2016) Drivers, dynamics and epidemiology of antimicrobial resistance in animal production. Food and Agriculture Organization of the United Nations, Rome ISBN 978-92-5-109441-9

Fasina FO, Olaokun OO, Oladipo OO, Fasina MM, Makinde AA, Heath L, Bastos AD (2013) Phytochemical analysis and in-vitro anti-African swine fever virus activity of extracts and fractions of Ancistrocladus uncinatus, Hutch and Dalziel (Ancistrocladaceae). BMC Vet Res 9: 120

FSSAI (2018) Interim report, National milk safety and quality survey 13 November 2018. Food Safety and Standards Authority of India, Ministry of Health and Family Welfare, Government of India, New Delhi

Ganguly B, Mrigesh M, Chauhan P, Rastogi SK (2020) Dietary supplementation with Withania somnifera root powder ameliorates experimentally induced Infectious Bursal Disease in chicken. Trop Anim Health Prod 52: 1195-1206.

Gaurav A, Gill JPS, Aulakh RS, Bedi JS (2014) ELISA based monitoring and analysis of tetracycline residues in cattle milk in various districts of Punjab. Vet World 7: 26-29

GOI (2017) National Action Plan on Antimicrobial Resistance (NAPAMR) 2017-2021. Ministry of Health and Family Welfare, Government of India, New Delhi

Groot MJ, van't Hooft KE (2016) The hidden effects of dairy farming on public and environmental health in the Netherlands, India, Ethiopia, 
and Uganda, considering the use of antibiotics and other agrochemicals. Front Public Health 4:12

Harikumar AV, Dutta P, Shroff S, Sharma GK, Patel AS, Patel NA, Patel SB (2015) An introduction to the 'Animal Health Module' of INAPH software. Indian Dairyman 67: 60-66

Hebbal MA, Latha C, Menon KV, Deepa J (2020) Occurrence of oxytetracycline residues in milk samples from Palakkad, Kerala, India. Vet World 13: 1056-1064.

Iqbal Z, Jabbar A, Akhtar MS, Muhammad G (2005) Possible role of ethnoveterinary medicine in poverty reduction in Pakistan: Use of botanical anthelmintic as an example. J Agric Soc Sci 1: 187-195

Jeyathilakan N, Murali K, Anandaraj A, Abdul Basith S (2012) In vitro evaluation of anthelmintic property of ethno-veterinary plant extracts against the liver fluke Fasciola gigantica. J Parasit Dis 36: $26-30$

Kaewprom K, Chen Y-H, Lin C-F, Chiou M-T, Lin C-N (2017) Antiviral activity of Thymus vulgaris and Nepeta cataria hydrosols against porcine reproductive and respiratory syndrome virus. Thai J Vet Med 47: $25-33$

Kalla A, Kutcharlapati SR, Gannavarapu SB, Layam A (2015) Isolation and identification of specific pathogens, presence of antibiotics, aflatoxins, pesticide residues and industrial contaminants in supply chain of milk in elected coastal districts of Andhra Pradesh. Adv Biosci Biotechnol 6: 330-344

Kpodékon TM, Ogni CA, Dassou H, Dougnon TJ, Boko C, Koutinhouin GB, Goussanou JSE, Akoegninou A, Youssao I (2015) Dominant viral pathologies in the extensive and semi-intensive animal breeding and their treatment mode in ethno veterinary medicine in Benin. Vet World 8: 1424-1434

Kumari S, Kumar S, Prasad A, Sahay S, Kumar R, Minj N, Ahmad T (2020) A study on antibiotic sensitivity test of methicillin resistant and non methicillin resistant Staphylococcus aureus from mastitic milk. J Entomol Zool Stud SP8: 77-79.

Kumarswamy N, Latha C, Menon V, Sethukekshmi C, Mercy K (2018). Detection of antibiotic residues in raw cow milk in Thrissur, India. Pharma Innov J 7: 452-454.

Lejaniya A, Sathya P, Sathian C, Anil K, Geetha R, Radha K (2017). Screening of pooled milk samples for beta lactam and tetracycline antibiotic residues. Int J Sci Environ Technol 7: 79-84

Lundén H (2015) What's in the millk? Aflatoxin and antibiotic residues in cow's milk in Assam, Northeast India. Dissertation, Swedish University of Agricultural Science, Uppsala. ISSN:1652-8697 https:// stud.epsilon.slu.se/8196/7/lunden_h_160112.pdf Accessed 11 September 2020

Mahanti A, Joardar SN, Bandyopadhyay S, Banerjee J, Ghosh S, Batabyal K, Sar TK, Dutta TK, Samanta I (2020) Characterization of methicillin-resistant and enterotoxins producing Staphylococcus aureus in bovine milk in India. J Agric Food Res 2: 100017

Manimaran K, Balakrishnan S, Sangeetha A, Venkatesh A, Sivakumar T (2020) Methicillin resistant Staphylococcus aureus mastitis in dairy cows in Thanjavur, Tamil Nadu. J Entomol Zool Stud 8: 164-167

Manzoor A, Muhammad G, Deeba F, Arshad MI (2020) Therapeutic evaluation of an out of the box oral non-antibiotic formulation against clinical mastitis in buffaloes. Pak J Agric Sci 57: 269-274

Marume A, Matope G, Katsande S, Khoza S, Mutingwende I, Mduluza T, Munodawafa-Taderera T, Ndhlala AR (2017) Wound healing properties of selected plants used in ethnoveterinary medicine. Front Pharmacol 8: 544

Mayer M, Vogl CR, Amorena M, Hamburger M, Walkenhorst M (2014) Treatment of organic livestock with medicinal plants: A systematic review of European ethnoveterinary research. Complement Med Res 21: $375-386$
McCorkle C (1998) Ethnoveterinary medicine. In Schoen A, Wynn S (ed) Complementary and alternative veterinary medicine. Mosby Elsevier, St. Louis, Mo, USA pp. 713-741

Moudgil P, Bedi JS, Aulakh RS, Gill JPS (2019) Antibiotic residues and mycotoxins in raw milk in Punjab (India): a rising concern for food safety. J Food Sci Technol 56: 5146-5151

Nair MNB (2019) Ethno-Veterinary sciences and practices for reducing the use of antimicrobial and other veterinary drugs in veterinary practices. EC Veterinary Science RCO.01:16-17

Nair MNB, Punniamurthy N (2017) Ethno-veterinary Formulation for Treatment of Bovine Mastitis. Research and Reviews: J Vet Sci 1: 25-29

Nair MNB, Punniamurthy N, Kempanna K (2015). Role of ethnoveterinary practices (EVP) in reducing antimicrobial resistance in livestock production systems: a field experience. Planta Med 81:SL3C_06. doi: 10.1055/s-0035-1565325

NAVS (2015a) Human resource needs in veterinary and animal sciences. Policy paper No. 2. National Academy of Veterinary Sciences (India), New Delhi. http://www.navsindia.org/downloads/files/ n593137c054c72.pdf

NAVS (2015b) Ethnoveterinary medicine: A concept for sustainable livestock production. Policy Paper No 3. National Academy of Veterinary Sciences (India), New Delhi. http://www.navsindia.org/ downloads/files/n593137a7cc048.pdf

Nimbalkar S, Patil D, Deo A (2020) Ethnoveterinary practices (EVP) for control of ectoparasite in livestock. Indian J Tradit Know 19: 401405

Nirala R, Anjana K, Mandal K, Jayachandran C (2017) Persistence of antibiotic residue in milk under region of Bihar, India. Int J Curr Microbiol Appl Sci 6: 2296-2299.

Nyahangare ET, Mvumi BM, Mutibvu T (2015) Ethnoveterinary plants and practices used for ecto-parasite control in semi-arid smallholder farming areas of Zimbabwe. J Ethnobiol Ethnomedicine 11: 30

Olivares E, Badel-Berchoux S, Provot C, Prévost G, Bernardi T, Jehl F (2020) Clinical impact of antibiotics for the treatment of Pseudomonas aeruginosa biofilm infections. Front Microbiol 10:2894 doi: 10.3389/fmicb.2019.02894

Rana SK, Harikumar AV, Dutta P, Surendra KSNL, Bahekar VS, Ponnanna NM, Sharma GK. (2019) Mastitis control/ : A sustainable model for the developing world in IDF Animal Health Report No. 13, International Dairy Federation. Brussels, Belgium. pp 23-26

Ranganathan V (2017) Ethnoveterinary practices for combating antimicrobial resistance. Int J Sci Environ Technol 6: 840-844

Rastogi S, Pandey M, Prakash J, Sharma A, Singh G (2015) Veterinary herbal medicines in India. Pharmacogn Rev 9: 155-163

Sanhokwe M, Mupangwa J, Masika PJ, Maphosa V, Muchenje V (2016) Medicinal plants used to control internal and external parasites in goats. Onderstepoort J Vet Res 83: 1016

Shah MS, Qureshi S, Kashoo Z, Farooq S, Wani SA, Hussain MI, Banday MS, Khan AA, Gull B, Habib A, Khan SM, Dar BA(2019) Methicillin resistance genes and in vitro biofilm formation among Staphylococcus aureus isolates from bovine mastitis in India. Comp Immunol Microbiol Infect Dis 64: 117-124

Sharma V, Sharma S, Dahiya DK, Khan A, Mathur M, Sharma A (2017). Coagulase gene polymorphism, enterotoxigenecity, biofilm production, and antibiotic resistance in Staphylococcus aureus isolated from bovine raw milk in North West India. Ann Clin Microbiol Antimicrob 16: 65

Silver R (2007) Ayurvedic veterinary medicine: principles and practices. In Wynn SG and Fugere B (ed) Veterinary Herbal Medicine. Mosby Elsevier, St. Louis, Mo. pp. 61-83

Sivakumar M, Abass G, Vivekanandhan R, Anukampa, Singh DK, Bhilegaonkar K, Kumar S, Grace MR, Dubal Z (2020) Extended- 
spectrum beta-lactamase (ESBL) producing and multidrug-resistant Escherichia coli in street foods: a public health concern. J Food Sci Technol https://doi.org/10.1007/s13197-020-04634-9

Sudershan RV, Bhat RV (1995) A survey on veterinary drug use and residues in milk in Hyderabad. Food Addit Contam 12: 645-650

Van Boeckel TP, Gandra S, Ashok A, Caudron Q, Grenfell BT, Levin, SA, Laxminarayan R (2014) Global antibiotic consumption 2000 to 2010: an analysis of national pharmaceutical sales data. Lancet Infect. Dis. 14: 742-750

WHO (2015) Global action plan on antimicrobial resistance. World Health Organization. Geneva ISBN: 9789241509763

WHO (2019). UN-Interagency Coordination Group (IACG) on Antimicrobial Resistance. Final Report. No time to wait: Securing the future from drug-resistant infections. World Health Organization. Geneva.

WHO (2018) Monitoring global progress on addressing antimicrobial resistance. Analysis report of the second round of of AMR country self-assessment survey 2018. World Health Organization. Geneva. ISBN: 9789241514422

WHO (2016). Antimicrobial resistance, a manual for developing national action plans. World Health Organization. Geneva. ISBN: 9789241549530

Zitterl-Eglseer K, Marschik T (2020) Antiviral medicinal plants of veterinary importance: A literature review. Planta Med. doi: https:/ /doi.org/10.1055/a-1224-6115 